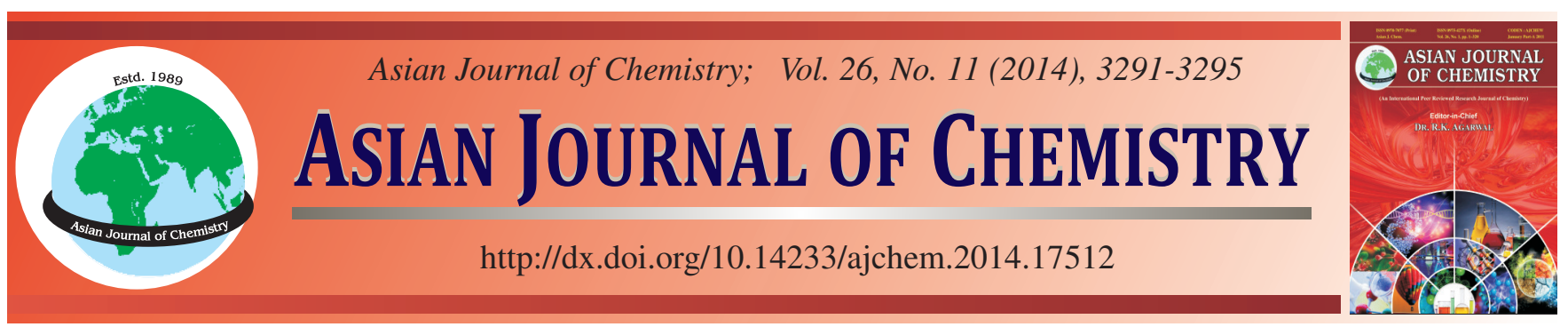

\title{
Income Growth of Peasants with Enterprise Entering Using DID Model-Based on 260 Samples of Farmers in Jinzhong City, China
}

\author{
Caifen Zhang ${ }^{1}$, Lijuan Guo $^{1}$, Shasha Xue ${ }^{1}$ and Fuzhong $\mathrm{Li}^{1,2, *}$
}

${ }^{1}$ Shanxi Agricultural University Economic and Trade College, Taigu 030801, Shanxi Province, P.R. China

${ }^{2}$ Software College, Taigu 030801, Shanxi Province, P.R. China

*Corresponding author: Tel/Fax: +86 354 6287093; E-mail: sxaulfz@126.com

\begin{abstract}
In anticipation of building a moderately prosperous society in 2020 and doubling the income of urban and rural residents, through field investigation on 260 microscopic farmers from 16 villages in Jinzhong City of China, this paper built Difference-in-Difference Model and made comparative analysis for the income growth of farmers overall, different income channels and landless farmers before and after agricultural enterprises entering. The results show that: firstly, the entering of agricultural enterprises made the peasants income improve 28184 Yuan and the income increased sustainability; secondly, three income channels have significant positive effect and the role of radiation channel is strongest; thirdly, during the observation period, the entering of enterprise made more contribution to landless farmers than un-landless farmers. The income growths of landless farmers mainly come from the non-farm business. Finally, the article put forward corresponding policy recommendations to solve land disputes, income disparity and unbalance on land price with the entering of enterprise.
\end{abstract}

Keywords: Enterprise entering, Income growth of peasants, Income channels, DID model.

\section{INTRODUCTION}

Rural development is the most important task in China. So far, China has continuously introduced 10 documents on rural issues. With the adjustment and optimization of industrial structure, the key point of support for agriculture has also changed. The report on 18th National Congress of the Communist Party of China has presented a great goal that on building moderately prosperous society by 2020 . How to promote the farmers' income is the emphasis and difficulty to achieve this goal. At present the purchase price of agricultural products is low, agricultural technology progress is slow, the output per unit of land is not high, agricultural subsidies is limited, so take the path of agricultural modernization management become a inevitable trend for farmers to increase production. As a carrier and link of agricultural industrialization, enterprise is superior to the farmers on capital, technology, management and discourse power. The entering of enterprise will give play to "learning effect" which can promote industry agglomeration and increase farmers' discourse power, so it's the dominant force in driving farmers to achieve agricultural modernization operations and increasing the farmers' income. What role does enterprise play on increasing farmer's income? Some scholars have discussed from different angles ${ }^{1}$. Xuguang et al. take Nanjing as an example to verify that enterprise has a significant effect on increasing farmers' income from the perspective of connection mechanism between enterprise and farmers. The article draws a conclusion that orders have higher income through getting technical guidance and higher purchase price, reducing transportation cost from the enterprise ${ }^{2}$. Yupeng et al. ${ }^{3}$ analyze the influence factors of agricultural industrialization promoting farmers' income growth by using survey data of 857 farmers in 5 counties in Hebei province. The empirical results based on Probit model show that number of enterprises, enterprise scale, closeness and time of cooperation between farmers and enterprises generate positive effects on farmers' income, of which enterprise scale influent the highest ${ }^{3}$.

These studies confirmed that the enterprise entering can actually increase farmers' income, but the analysis just made on the whole and not do classification research on the mode and channel of farmers' income. How about the performance that enterprises lead to farmers' income? In what ways and channels is driven incomes? Under which way is the performance most significant? To answers these questions, we need 
make an empirical analysis about enterprises and farmers from time and space. Based on the existing research and field investigation, the authors of this article, divides income approach into three categories: direct, indirect and radiation according to connecting mode between farmers and enterprises. The article build difference-in-differences model from time and space to make empirical analysis on the performance of three kinds. We are looking forward to get some new and significative conclusions.

\section{EXPERIMENTAL}

\section{Hypothesis and model}

Hypothesis: In China, rural household income mainly consists of the following aspects: household operating income, wage income, transfer income and property income at present. According to the research need, this article will divide the household operating income into agricultural operating income and non-agricultural operating income ${ }^{4}$; wage income refers to labor income; transfer income mainly refers to the policyrelated subsidies from government; property income includes rent, the rent of peasant household land mobility, etc. After enterprises settles in rural areas, the different connection form between rural household and enterprises will lead to different channels of increasing farmers' income and different certainty of getting income. Some farmers become shareholders by leasing land or turning lands into stocks to share business income and the certainty of this channel is high and farmers do not invest time and energy, so we will define it as direct income. It increases farmers' income by increasing property income. Some farmers enter enterprises to participate in the work and obtain the wage income and the certainty of this channel is low, wage will be different with different laborer technology, quality and physical strength. And it needs farmers to invest time and energy, so we will define it as indirect income. Some farmers carry out agricultural production by imitating the management way of enterprise, they also extend the industrial chain to provide service for production and consumption and the certainty of this channel is lowest, it can not be only influenced by farmers' ability to learn and family capital strength, but also decided by farmers differentiation in different industries and it needs farmers pay money and work. In this channel farmers hardly participate in business operation, we called it radiation income. Radiation income may be related to farmers' property income, agricultural operating income, non-agricultural operating income, transfer income and so on.

In theory, there are many factors to promote farmers' income. These factors must be under control when we are doing research on the performance of enterprises settlement to the farmers' income and we can make a causal relationship between enterprises and farmers' income. According to relevant literature, the factors that affect farmers' income will be divided into policy factors, resource factors and family factors in accordance with the principle of combination of macro and micro. Firstly, the policy factors impact on farmers' income mainly through minimum purchase price of agricultural products and grain subsidies. We select the purchase price of main grain crops and the amount of subsidy per mu of cultivated land two indicators; secondly, resource factors impact on farmers' income by the amount of resources that farmers own, so we select the number of arable and population in the working age two indicators; Finally, family factors impact on farmers' income by the industry in which the labor force are engaged and laborer quality and technology, so we select non-agricultural population in rural households and the number of college students two indicators.

Model: Double-difference method is an econometric approach that can be used to calculate the net impact of a policy, action or event on its object ${ }^{5}$. This method can simultaneously control the time-varying factors and the afterwards difference between treatment group and control group and it can effectively verify the causal relationship that the policy (events) bring net earnings on the object. It is widely used at home and abroad due to the scientific nature and rationality. In 1994, Gruber first used double-difference method to study the effect of tax reform on residents' willingness to buy personal insurance $^{6}$. In 2009, Alvaez also used the method to study the effect of trade liberalization on industrial dynamics ${ }^{7}$. Doubledifference method is not common in domestic applications. The current scholars mainly use it for policy effect research. For example, in 2005 Zhou and $\mathrm{Chen}^{8}$ used this method to explore the policy effect of Chinese rural tax reform; in 2010 Nan and Zhen ${ }^{9}$ also used this method to analyze empirically the effects of state-owned enterprise restructuring policy.

Enterprises located in rural areas engages in agricultural production and it promotes gradually farmers' income, which will result in double differences: On one hand, there exists farmers income gap before and after enterprises settling in the same rural area; on the other hand, there exists farmers income gap at the same time after enterprises settling in different rural area. Given the dual nature of the income gap, this article selects the double-difference method and the rural areas where enterprises settle as a "treatment group" and rural areas that enterprises don't settle as a "control group". We can identify the performance of enterprises settlement on different type's farmers' income by carrying quantitative calculation on farmers' income situation for the treatment and control groups in the time series. The equation that uses the linear regression model to build is as follows:

$$
Y_{\text {it }}=\beta_{0}+\beta_{1} \text { group }+\beta_{2} \text { time }+\delta \text { group } \times \text { time }+\sum \alpha_{i} X_{i t}+\varepsilon_{i t}(1)
$$

where, i represents individuals in the survey sample. $t$ represents time. And group is the virtual variables between groups. group $=1$ indicates enterprises settled. group $=0$ means no enterprises settled; time is the virtual variables for time. time $=0$ means the period before enterprises settled, time $=1$ means the current year when enterprises settled, time $=2$ means the first year after enterprises settled, time $=3$ means the second year after enterprises settled; $\delta$, double-difference statistics, is used to measure the net income of farmers due to the enterprises settlement; $\Sigma \mathrm{X}$ is a set of control variables that affect possibly farmers' income, we mainly selected purchase price, the amount of subsidy per mu of arable land, the number of arable land, the population in working age, the number of nonagricultural population and whether there are college students six variables; $\varepsilon$ is a random disturbance term; $Y$ represents the income of the surveyed households and we classify $Y$ according to different research purposes. $\mathrm{Y}_{\text {all }}$ is the total income. $\mathrm{Y}_{\text {pattern }}$ 
represents farmers income under different modes of participation in enterprises management. $Y_{\text {source }}$ represents household income from different sources. According to the formula (1), farmers' income of treatment group before and after enterprises settled is as follows:

$$
\begin{gathered}
Y=\left\{\begin{array}{l}
Y_{i 1}=\beta_{0}+\beta_{1}+\beta_{2}+\delta+\sum a_{i} X_{i 1}+\varepsilon_{i 1}, \text { time }=1 \\
Y_{i 0}=\beta_{0}+\beta_{1}+\sum a_{i} X_{i} 0+\varepsilon_{i} 0, \text { time }=0
\end{array}\right\} \\
Y_{i 1}-Y_{i 0}=\beta_{2}+\delta+\left(\sum \mathrm{aiX}_{\mathrm{i} 1}-\sum \mathrm{aiX}_{\mathrm{i} 0}\right)+\left(\varepsilon_{\mathrm{i} 1}-\varepsilon_{\mathrm{i} 0}\right)
\end{gathered}
$$

Similarly, farmers' income of control group before and after enterprises settled is as follows:

$$
\begin{aligned}
& Y^{\prime}=\left\{\begin{array}{l}
Y_{i 1}=\beta_{0}+\beta_{2}+\delta+\sum a_{i} X_{i 1}+\varepsilon_{i 1}, \text { time }=1 \\
Y_{i 0}=\beta_{0}+\sum a_{i} X_{i} 0+\varepsilon_{i 0}, \text { time }=0
\end{array}\right\} \\
& \mathrm{Y}_{\mathrm{i} 1}{ }^{\prime}-\mathrm{Y}_{\mathrm{i} 0}{ }^{\prime}=\beta_{2}+\left(\Sigma_{\mathrm{ai}} \mathrm{X}_{\mathrm{i} 1}-\Sigma \mathrm{aiX}_{\mathrm{i} 0}\right)+\left(\varepsilon_{\mathrm{i} 1}-\varepsilon_{\mathrm{i} 0}\right)
\end{aligned}
$$

Finally, we can calculate farmers' income when the enterprises settled in $=\left(Y_{i 1}-Y_{i 0}\right)-\left(Y_{i 1}-Y_{i 0}{ }^{\prime}\right)=\delta$. Therefore, the core content of this study is ' $\delta$ ', $\delta>0$ means enterprise settlement plays a positive role on $\mathrm{f}$ farmers' income, the value of is stronger, greater role is played; conversely, $<0$ indicates that enterprise settlement damages the interests of farmers and it plays a negative role on farmers' income.

\section{Data sources and statistical description}

Data sources: The data used in this study is from field surveys in April 2013 for 260 rural households in four towns (townships) 16 villages from Jinzhong City in Shanxi Province. We selected 2 villages where enterprises settle and 2 villages where enterprises do not settle in each town. We collected 244 valid samples in total. Among them, 76 households are in villages with enterprises settlement, 168 households are in villages without enterprises settlement. We use the stratified sampling method to classify the households who are in the village with enterprises settlement according to the different sources. The authors selected two villages have a pre-survey before the investigation. Then the questionnaire is modified and improved combined with the data reduction and actual situation. So the collected data is normative and rigorous. In addition, we selected the survey area where enterprises settled at the same time (no more than around 4 months) to eliminate the time factor.

Statistical description: Table-1 shows the households basic characteristics in treatment and control groups before and after the companies settled. By comparison there is no exist significant differences between villages with enterprises settlement and villages without enterprises settlement in the amount of labor, number of college students, purchase price of grain, the subsidy of arable land, but there are quite difference in the amount of arable land and nonfarm payrolls. Amount of arable land in control group is higher than the treatment group, while nonfarm payrolls in control group fell much more than the treatment group. The net income of the family in control group is higher than the treatment group before enterprises settle and the current year when enterprises settle, but the net income of the family in control group is significantly lower than the treatment group in the first and

\begin{tabular}{|c|c|c|c|c|c|c|c|c|}
\hline \multirow{3}{*}{ Variable } & \multicolumn{7}{|c|}{$\begin{array}{l}\text { TABLE-1 } \\
\text { BASIC CHARACTERISTIC OF FARMERS BEFORE AND AFTER THE ENTERPRISE } \\
\text { ENTERING BETWEEN TREATMENT AND CONTROL GROUP }\end{array}$} & \\
\hline & \multicolumn{4}{|c|}{ Control group } & \multicolumn{4}{|c|}{ Treatment group } \\
\hline & $\mathrm{t}=0$ & $t=1$ & $t=2$ & $t=3$ & $\mathrm{t}=0$ & $\mathrm{t}=1$ & $\mathrm{t}=2$ & $t=3$ \\
\hline $\begin{array}{l}\text { Rural household } \\
\text { income (Yuan) }\end{array}$ & $\begin{array}{c}66790 \\
(15408)\end{array}$ & $\begin{array}{c}70144 \\
(68499)\end{array}$ & $\begin{array}{c}68199 \\
(60973)\end{array}$ & $\begin{array}{c}63210 \\
(52536)\end{array}$ & $\begin{array}{c}49489 \\
(61413)\end{array}$ & $\begin{array}{c}60646 \\
(63222)\end{array}$ & $\begin{array}{c}107715 \\
(226050)\end{array}$ & $\begin{array}{c}125301 \\
(328740)\end{array}$ \\
\hline $\begin{array}{c}\text { Agricultural } \\
\text { operating income }\end{array}$ & $\begin{array}{c}39500 \\
(16395)\end{array}$ & $\begin{array}{c}49345 \\
(77425)\end{array}$ & $\begin{array}{c}38858 \\
(61514)\end{array}$ & $\begin{array}{c}40993 \\
(52812)\end{array}$ & $\begin{array}{c}25602 \\
(57830)\end{array}$ & $\begin{array}{c}24551 \\
(62039)\end{array}$ & $\begin{array}{c}28890 \\
(61754)\end{array}$ & $\begin{array}{c}27423 \\
(63223)\end{array}$ \\
\hline $\begin{array}{l}\text { Non-agricultural } \\
\text { operating income }\end{array}$ & $6843(5075)$ & $\begin{array}{c}35000 \\
(43589)\end{array}$ & $\begin{array}{c}7368 \\
(23056)\end{array}$ & $\begin{array}{c}80000 \\
(14142)\end{array}$ & $\begin{array}{c}11317 \\
(32183)\end{array}$ & $\begin{array}{c}14674 \\
(34418)\end{array}$ & $\begin{array}{c}54647 \\
(223317)\end{array}$ & $\begin{array}{c}72347 \\
(332329)\end{array}$ \\
\hline Wage income & $\begin{array}{l}20295 \\
(4904)\end{array}$ & $\begin{array}{c}28271 \\
(20620)\end{array}$ & $\begin{array}{c}34442 \\
(19487)\end{array}$ & $\begin{array}{c}35042 \\
(19169)\end{array}$ & $\begin{array}{c}15048 \\
(19223)\end{array}$ & $\begin{array}{c}17312 \\
(19757)\end{array}$ & $\begin{array}{c}19078 \\
(20455)\end{array}$ & $\begin{array}{c}21776 \\
(21894)\end{array}$ \\
\hline Transfer income & $\begin{array}{c}153 \\
(31.22)\end{array}$ & $\begin{array}{l}230.91 \\
(136.2)\end{array}$ & $\begin{array}{l}196.67 \\
(199.9)\end{array}$ & $\begin{array}{l}363.82 \\
(212.5)\end{array}$ & $\begin{array}{l}159.99 \\
(263.9)\end{array}$ & $\begin{array}{l}111.74 \\
(258.5)\end{array}$ & $\begin{array}{c}243.45 \\
(711)\end{array}$ & $\begin{array}{c}260.62 \\
(712.21)\end{array}$ \\
\hline Property income & $\begin{array}{c}0 \\
(0.00)\end{array}$ & $\begin{array}{l}227.37 \\
(685.7)\end{array}$ & $\begin{array}{c}31.58 \\
(137.6)\end{array}$ & $\begin{array}{c}84.21 \\
(367.1)\end{array}$ & $\begin{array}{l}290.71 \\
(1851)\end{array}$ & $\begin{array}{l}5315 \\
(5006)\end{array}$ & $\begin{array}{c}5580 \\
(4982)\end{array}$ & $\begin{array}{c}5344 \\
(5045)\end{array}$ \\
\hline Purchase price & $\begin{array}{c}0.8 \\
(0.00)\end{array}$ & $\begin{array}{c}0.9 \\
(0.00)\end{array}$ & $\begin{array}{c}0.96 \\
(0.00)\end{array}$ & $\begin{array}{c}1.1 \\
(0.00)\end{array}$ & $\begin{array}{c}0.8 \\
(0.00)\end{array}$ & $\begin{array}{c}0.9 \\
(0.00)\end{array}$ & $\begin{array}{c}0.957 \\
(0.013)\end{array}$ & $\begin{array}{c}1.1 \\
(0.057)\end{array}$ \\
\hline $\begin{array}{l}\text { Number of } \\
\text { cultivated land }\end{array}$ & $\begin{array}{c}7.06 \\
(1.057)\end{array}$ & $\begin{array}{c}6.62 \\
(4.86)\end{array}$ & $\begin{array}{c}6.62 \\
(4.86)\end{array}$ & $\begin{array}{c}6.35 \\
(5.08)\end{array}$ & $\begin{array}{c}6.76 \\
(5.75)\end{array}$ & $\begin{array}{l}4.95 \\
(6.19)\end{array}$ & $\begin{array}{c}5.67 \\
(6.67)\end{array}$ & $\begin{array}{c}5.67 \\
(6.68)\end{array}$ \\
\hline Farmland subsidies & $\begin{array}{c}35 \\
(0.00)\end{array}$ & $\begin{array}{c}35 \\
(0.00)\end{array}$ & $\begin{array}{c}50 \\
(0.00)\end{array}$ & $\begin{array}{c}60 \\
(0.00)\end{array}$ & $\begin{array}{c}35 \\
(0.00)\end{array}$ & $\begin{array}{c}35 \\
(0.00)\end{array}$ & $\begin{array}{l}49.29 \\
(3.23)\end{array}$ & $\begin{array}{l}57.86 \\
(5.96)\end{array}$ \\
\hline Quantity of labor & $\begin{array}{c}2.16 \\
(0.257)\end{array}$ & $\begin{array}{c}2.16 \\
(1.12)\end{array}$ & $\begin{array}{c}2.21 \\
(1.18)\end{array}$ & $\begin{array}{c}2.21 \\
(1.18)\end{array}$ & $\begin{array}{c}2.71 \\
(1.09)\end{array}$ & $\begin{array}{c}2.71 \\
(1.09)\end{array}$ & $\begin{array}{c}2.69 \\
(1.07)\end{array}$ & $\begin{array}{c}2.67 \\
(1.07)\end{array}$ \\
\hline $\begin{array}{l}\text { Non-agricultural } \\
\text { population }\end{array}$ & $\begin{array}{c}0.63 \\
(0.175)\end{array}$ & $\begin{array}{c}0.63 \\
(0.761)\end{array}$ & $\begin{array}{c}0.68 \\
(0.82)\end{array}$ & $\begin{array}{c}0.68 \\
(0.82)\end{array}$ & $\begin{array}{c}0.88 \\
(1.02)\end{array}$ & $\begin{array}{c}0.88 \\
(1.02)\end{array}$ & $\begin{array}{c}0.93 \\
(1.05)\end{array}$ & $\begin{array}{c}0.93 \\
(1.05)\end{array}$ \\
\hline Student numbers & $\begin{array}{c}0.21 \\
(0.123) \\
\end{array}$ & $\begin{array}{c}0.26 \\
(0.562) \\
\end{array}$ & $\begin{array}{c}0.37 \\
(0.597) \\
\end{array}$ & $\begin{array}{c}0.47 \\
(0.697) \\
\end{array}$ & $\begin{array}{c}0.14 \\
(0.417) \\
\end{array}$ & $\begin{array}{c}0.14 \\
(0.417) \\
\end{array}$ & $\begin{array}{c}0.19 \\
(0.455) \\
\end{array}$ & $\begin{array}{c}0.21 \\
(0.47) \\
\end{array}$ \\
\hline Samples number & \multicolumn{4}{|c|}{76} & \multicolumn{4}{|c|}{168} \\
\hline
\end{tabular}
second year after enterprises settled. On the aspect of income structure, agricultural operating income and transfer income in treatment group is lower than the control group, which may

Note: Data in the table is calculated depending on the field investigation. Data in "()" is standard deviation. 
be affected by the amount of arable land. While treatment group is far superior in non-agricultural operating income and property income, especially in the first year after enterprises settled.

Through the statistical description on basic characteristics of households, we can see that farmers' income got a substantial increase after enterprises settled. However, there are still three questions need answers. First, is the increase of household income caused by the enterprises settled or other factors? Second, what channels farmers' income increased by enterprises settlement through and which channel the most obvious role is played? Third, the companies' settlement occupied land. Is the effect that increases income consistent for landless farmers and non-landless farmers? And is current land compensation reasonable for farmers? These questions can not be explained clearly as in descriptive statistics, so the author will use the double-difference method to discuss and evaluate the effects on farmers' income after enterprises settled below.

\section{RESULTS AND DISCUSSION}

In response to these questions, this article makes regression analysis from three stages using EVIEWS5.1 software. The regression results are shown in Table-2.

Step 1: Model 1 makes empirical analysis on overall income performance carried by enterprises' settlement. In this analysis we put in six control variable and the empirical results show that agricultural enterprises enter can actually increase farmers' income. Model 1shows that dependent variable: whether companies settled, time dummies, interaction items and control variables: grain purchase price, the number of family farmland and farmland subsidies produce significant effect on dependent variable net income of farm household. Each of variables makes positive effect on income. In model, the time-varying coefficient is 3206 and the results show that the net income of farm household of both treatment group and control group has got increased. Group coefficient was 24002 , which indicates that under the premise of no timevarying control, the net income of rural households in villageowned enterprises is more 24002 Yuan than others. If we control time and group at the same time, we can find the interaction coefficient are 28184 . The coefficient is significant at $1 \%$ level, which indicates that the settlement of enterprises has obvious positive effect on farmers' income performance. This result means that the level of household income has been greatly improved after agricultural enterprises settling in rural, which is in accordance with the statistical description results above. In addition, from the timing point of view, the impact enterprises settling made on the performance of farmers' income is expansile as time progresses.

Step 2: The author divides income approach into three categories: direct, indirect and radiation according to connecting mode between farmers and enterprises. In this paper, we will make empirical analysis from the three aspects by building the model 2 , model 3 and model 4 . Model 2 indicate that in addition to the grain purchase price, nonagricultural population and student numbers, the rest of variables have significant impact on revenue. Among them, just the quantity of cultivated land and the amount of subsidies have negative impact on income. The reason is that the direct income is mainly refers to the rent of the cultivated land enterprise provide to farmers, which is rising with the reduction in the number of cultivated land. In model 3, only the number of labor has significant effects on indirect income. The result reflects that the remuneration enterprises pay for labor is low, so farmers are willing to work for the enterprise only when they are free. In model 4 , the number of cultivated lands makes

TABLE-2

PARAMETERS ESTIMATION AND STATISTICAL TEST RESULTS

\begin{tabular}{|c|c|c|c|c|c|c|}
\hline Variable & Model 1 & Model 2 & Model 3 & Model 4 & Model 5 & Model 5 \\
\hline Group & $\begin{array}{c}24002 * * * \\
(2.093)\end{array}$ & $\begin{array}{c}652.23 * * \\
(2.056)\end{array}$ & $\begin{array}{c}2498.5 \\
(-0.066)\end{array}$ & $\begin{array}{l}13136.4 \\
(0.543)\end{array}$ & $\begin{array}{c}41702 \\
(1.435)\end{array}$ & $\begin{array}{c}3182 \\
(1.407)\end{array}$ \\
\hline Time & $\begin{array}{c}3206 * * * \\
(2.500)\end{array}$ & $\begin{array}{c}1120.9 * * * \\
(2.709)\end{array}$ & $\begin{array}{c}-3931 * * * \\
(-2.372)\end{array}$ & $\begin{array}{c}-4497 * * * \\
(-4.95)\end{array}$ & $\begin{array}{c}18169 \\
(0.984)\end{array}$ & $\begin{array}{l}14015 \\
(1.304)\end{array}$ \\
\hline Time*group & $\begin{array}{c}28184 * * * \\
(3.328)\end{array}$ & $\begin{array}{c}692.82 * * * \\
(3.268)\end{array}$ & $\begin{array}{c}6775 * * * \\
(5.766)\end{array}$ & $\begin{array}{c}33725 * * * \\
(3.737)\end{array}$ & $\begin{array}{c}42139 * * * \\
(2.116)\end{array}$ & $\begin{array}{l}5581 * * * \\
(2.095)\end{array}$ \\
\hline Current Year & $\begin{array}{c}-6830 * * * \\
(2.068)\end{array}$ & $\begin{array}{c}4805 * * * \\
(4.145)\end{array}$ & $\begin{array}{c}6900 * * * \\
(4.670)\end{array}$ & $\begin{array}{c}35419 * * * \\
(4.009)\end{array}$ & $\begin{array}{c}-31941 * * * \\
(-2.483)\end{array}$ & $\begin{array}{c}-485.8 * * * \\
(-2.046)\end{array}$ \\
\hline First year & $\begin{array}{c}20773 * * * \\
(2.382)\end{array}$ & $\begin{array}{c}2328 * * * \\
(4.032)\end{array}$ & $\begin{array}{c}8287 * * * * \\
(4.159)\end{array}$ & $\begin{array}{c}48168 * * * \\
(2.075)\end{array}$ & $\begin{array}{c}29959 * * * \\
(2.753)\end{array}$ & $\begin{array}{c}4711^{* * * *} \\
(2 . .418)\end{array}$ \\
\hline Second year & $\begin{array}{c}21265 * * * \\
(2.107)\end{array}$ & $\begin{array}{c}1520 * * * \\
(4.014)\end{array}$ & $\begin{array}{c}13778 * * * \\
(2.773)\end{array}$ & $\begin{array}{c}54486 * * * \\
(2.276)\end{array}$ & $\begin{array}{c}31893 * * * \\
(2.858)\end{array}$ & $\begin{array}{c}5284 * * * \\
(2.216)\end{array}$ \\
\hline Purchase price & $\begin{array}{c}282.7 * * * \\
(2.433)\end{array}$ & $\begin{array}{c}1336.11 \\
(0.248)\end{array}$ & $\begin{array}{l}488.68 \\
(1.739)\end{array}$ & $\begin{array}{c}208.4 \\
(0.505)\end{array}$ & $\begin{array}{c}133 \\
(1.120)\end{array}$ & $\begin{array}{c}800 \\
(1.203)\end{array}$ \\
\hline $\begin{array}{c}\text { Number of } \\
\text { cultivated land }\end{array}$ & $\begin{array}{c}7527 * * * \\
(3.431)\end{array}$ & $\begin{array}{c}-94.94 * * * \\
(-4.544)\end{array}$ & $\begin{array}{l}-217.6 \\
(-1.377)\end{array}$ & $\begin{array}{l}5042 * * * \\
(2.454)\end{array}$ & $\begin{array}{c}6576 * * * \\
(2.629)\end{array}$ & $\begin{array}{l}8245 * * * \\
(13.726)\end{array}$ \\
\hline $\begin{array}{l}\text { Farmland } \\
\text { subsidies }\end{array}$ & $\begin{array}{c}1114 * * * \\
(2.350)\end{array}$ & $\begin{array}{c}-138.4 * * * \\
(-4.746)\end{array}$ & $\begin{array}{l}-459.8 \\
(1.879)\end{array}$ & $\begin{array}{c}399.8 \\
(0.594)\end{array}$ & $\begin{array}{c}1953 \\
(1.371)\end{array}$ & $\begin{array}{c}541 \\
(1.078)\end{array}$ \\
\hline Quantity of labor & $\begin{array}{c}9184 \\
(1.053)\end{array}$ & $\begin{array}{c}206.73 * * \\
(2.076)\end{array}$ & $\begin{array}{c}1272.8 * * \\
(2.007)\end{array}$ & $\begin{array}{c}-8602 \\
(-0.966)\end{array}$ & $\begin{array}{l}12320 \\
(1.592)\end{array}$ & $\begin{array}{c}10010 * * * \\
(2.205)\end{array}$ \\
\hline $\begin{array}{l}\text { Non-agricultural } \\
\text { population }\end{array}$ & $\begin{array}{c}-5119 \\
(0.593)\end{array}$ & $\begin{array}{l}-124.43 \\
(-0.943)\end{array}$ & $\begin{array}{c}3978.9 \\
(-0.752)\end{array}$ & $\begin{array}{c}-3915 \\
(-1.439)\end{array}$ & $\begin{array}{c}-9104 \\
(-0.434)\end{array}$ & $\begin{array}{c}4328 \\
(0.711)\end{array}$ \\
\hline Student numbers & $\begin{array}{l}-27109 \\
(1.435)\end{array}$ & $\begin{array}{l}-283.52 \\
(-1.266)\end{array}$ & $\begin{array}{l}-1141.3 \\
(-0.281)\end{array}$ & $\begin{array}{l}-12867 \\
(-0.665)\end{array}$ & $\begin{array}{l}-31595 \\
(-0.999)\end{array}$ & $\begin{array}{c}-14763 * * * \\
(-2.092)\end{array}$ \\
\hline
\end{tabular}

Note: Figures in brackets are t test value, $* * *, * * *$ denote variables are significant at $1 \%, 5 \%, 10 \%$ level. 
significant effect on the radiation income, which indicates that enterprises drive farmers' income mainly through agriculture management. The result also show that the level of agricultural intensification is low at present in our country, which makes the increase of farming incomes highly dependent on the amount of cultivated land. Observed from the time sequence we find, interaction coefficients are positive in model 2, 3, 4 . It means enterprises drive farmers' income through the three kinds of channels and the most prominent is radiation increase. Meanwhile, the rent allocation is according to the straightline method and the household income is improving during observation years, which leads performance of direct income to decline in the timing. The performance of indirect and radiation income continues to improve. On the one hand, it shows the demand for labor is increasing with the expansion of business scale. On the other hand, it indicates that the industrial agglomeration in different degrees may cause peasant disintegration and strengthen the leading role of radiation.

Step 3: Because the increasing channel is not the same for land-lost farmers and non-land-lost farmers, this paper will make empirical research, respectively. The results are showed in model 5 and model 6. Land-lost farmers get rent after enterprise entering and the labor can be freed from the land. With abundant capital and labor support, the way of the farmers' income is very diverse. Both can choose to work for the enterprise and be engaged in service industry. For nonland-lost farmers, the enterprises drive farmers' income mainly through indirect and radiation increase. Through the regression results, we can find the interaction coefficients of land-lost farmers and non-land-lost farmers are 42139 and 5581, which indicates that the income increase after companies entering for the former is much higher than the latter. In addition, we also make classified study on different income approach for land-lost farmers, but limited by space we will not elaborate. Regression results show that the enterprises drive land-lost farmers' income mainly through non-farm operation. The income performance reached 25,782.08 Yuan, the agricultural management following is 2065.48 Yuan.

\section{Conclusion}

Base on field survey for 260 micro-farmers in Shan xi province, the author makes empirical analysis on income performance enterprises derived from three aspects: overall income increase, different channels, land-lost and non-landlost farmer by using difference-in-difference model. We get some conclusions according to the empirical results. Firstly, the entering of enterprises will assuredly make contribution to farmers' income and the effect can be sustainable. Secondly, in three kinds of income sources, the radiation increase makes the most significant effect, second is indirect income and finally is direct income. At the same time, indirect and radiation increase will show an upward trend increase as time progresses and expansion of business scale. Thirdly, the promoting effect on land-lost farmers is bigger than the non-land-lost farmers after enterprises entering during the observation period. The income increase of land-lost farmers is mainly from the nonagricultural business. This indicates that the settlement of companies will bring huge rent for landless farmers and liberate labor from agriculture, which make farmers have more opportunities and channels create income through tertiary industry.

In the field survey, we found that companies' settlement can increase farmers' income, but it may also bring some issues: part of farmers is out of work limited by skills, knowledge, physical and other constraints; the increase performance for non-land-lost farmers is low which may easily lead to internal rural disparity; the rising of land prices after enterprise entering will lead to the cost and difficulty increase for latter settlers. These problems need to be solved from the policy: firstly, in the process of land acquisition we must follow the principle of voluntary; for some farmers who are unwilling to rent land, the government can adopt exchange or rent the collective land and other ways to coordinate; village committee and enterprise need to train land-lost farmers prepensely to ensure farmers have the ability to engage in other industries after lose land. Secondly, government must carry out a rigorous screening for the enterprises settled in rural. Guide the enterprises having normative management, sufficient market information, advanced breeding technology to settle. Encourage enterprises to sign a cooperation agreement with farmers and reduce the production risk of peasant household by giving assistance to infrastructure, technology and sales channels. Thirdly, we need build system of income redistribution for previous landless farmers. Do our best to reduce the loss of previous landless farmers due to the price of land rose. As to how to develop a standard system of redistribution is a more complex project, but also worthy of our further research.

\section{ACKNOWLEDGEMENTS}

This study was sponsored by the Industrial Public Sector Research and Special of Ministry of Land and Resources (No. 201311088-03); the grant of Introduction of Talents of Shanxi Agricultural University (No. 200916).

\section{REFERENCES}

1. K.S. Jiang, S.L. Han and Z.F. Sha, Problem Agric. Econ., 24, 25 (2003).

2. X.G. Kuai, A. Jin and C. Chen, Chinese Agric. Sci. Bull., 24, 579 (2008).

3. Y.P. Liu, T. Li and H.F. Zhao, Jiangsu Agric. Sci., 40, 375 (2012).

4. O.X. Zhang and J.W. He, Technol. Econ., 28, 99 (2009).

5. B. Zhang and P.G. Zuo, J. Agrotech. Econ., 1, 98 (2009).

6. J. Gruber and J.M. Poterba, Quart. J. Econ., 109, 701 (1994).

7. A. Roberto and L. Ricardo, Trade Liberalization and Industry Dynamics: A Difference Indifference Approach (2009).

8. L.-A. Zhou and Y. Chen, Econ. Res. J., 8, 44 (2005).

9. N. Li and Z. Qiao, J. Quant. Techn. Econ., 2, 3 (2010). 